\title{
Improving Reading Skills Class VI Muhammadiyah Gantiwarno Elementary School through Learning Video Media
}

\author{
Nurhayati \\ SD Muhammadiyah Gantiwarno \\ nur275596@gmail.com
}

\section{Article History}

accepted 14/11/2020

approved 21/11/2020

published 26/11/2020

\begin{abstract}
The purpose of this study was to improve the learning outcomes of grade VI students of Muhammadiyah Gantiwarno Elementary School on reading skills through instructional video media. The research conducted was Classroom Action Research which was conducted in three cycles, where each cycle consisted of one meeting. The method in this research is carried out in four stages, namely planning, acting, observing, and reflecting. In the first cycle the learning outcomes of students seen from the class average reached 74.78 with completeness of the learning outcomes of students reaching 60.87\%, In cycle II the class average reached 76.09 with completeness of the learning outcomes of students reaching $69.56 \%$, while in cycle III the average was Class average reached 82.17 with completeness of student learning outcomes reaching $78.36 \%$. The conclusion in this study states that the use of instructional video media can improve the learning outcomes of grade VI students at Muhammadiyah Gantiwarno Elementary School, especially in reading skills.
\end{abstract}

Keywords: Learning outcomes, learning video media, reading skills

\begin{abstract}
Abstrak
Tujuan dari penelitian ini adalah untuk meningkatkan hasil belajar peserta didik kelas VI SD Muhammadiyah Gantiwarno pada keterampilan membaca melalui media video pembelajaran.Penelitian yang dilakukan adalah Penelitian Tindakan Kelas yang dilaksanakan sebanyak tiga siklus, di mana setiap siklusnya terdiri atas satu kali pertemuan. Metode dalam penelitian ini dilaksanakan dalam empat tahapan, yaitu perencanaan, tindakan, pengamatan, dan refleksi. Pada siklus I hasil belajar peserta didik dilihat dari rata-rata kelas mencapai 74.78 dengan ketuntasan hasil belajar peserta didik mencapai $60.87 \%$, Pada siklus II rata-rata kelas mencapai 76.09 dengan ketuntasan hasil belajar peserta didik mencapai $69.56 \%$, sedangkan pada siklus III rata-rata kelas mencapai 82.17 dengan ketuntasan hasil belajar peserta didik mencapai $78.36 \%$. Kesimpulan pada penelitian ini menyatakan bahwa penggunaan media video pembelajaran dapat meningkatkan hasil belajar peserta didik kelas VI Sekolah Dasar Muhammadiyah Gantiwarno, khususnya dalam keterampilan membaca.
\end{abstract}

Kata kunci: Hasil belajar, media video pembelajaran, keterampilan membaca

Social, Humanities, and Education Studies (SHEs): Conference Series p-ISSN 2620-9284 https://jurnal.uns.ac.id/shes

e-ISSN 2620-9292 


\section{PENDAHULUAN}

Menurut (Dimyati, 2006: 297) Pembelajaran adalah kegiatan guru secara terprogram dalam desain instruksional untuk membuat siswa belajar secara aktif yang menekankan pada penyediaan sumber belajar. Proses pembelajaran yang baik harus inovatif melalui sebuah media yang menarik supaya materi dapat diterima oleh peserta didik. Menurut Sudjana (2009: 3) hasil belajar peserta didik pada hakekatnya adalah perubahan tingkah laku. Tingkah laku hasil belajar dalam pengertian yang luas mencakup bidang kognitif, afektif, dan psikomotoris. Guru sebgai pemegang proses pembelajaran harus bisa menyajikan hal yang terbaik. Salah satunya dengan menggunakan media pembelajaran yang baik.Pemilihan media pembelajaran yang menarik akan mendukung hasil belajar peserta didik.

Menurut Tarigan (2008:7) membaca adalah suatu proses yang dilakukan serta dipergunakan oleh pembaca untuk memperoleh pesan yang hendak disampaikan oleh penulis melalui media kata-kata/bahasa tulis. Dalam kegiatan membaca melibatkan interaksi antara penulis dan pembaca melalui tulisan. Pembaca berusaha memahami makna atau isi dari tulisan yang disampaikan penulis. Membaca bergerak dari pengertian yang sederhana sampai pada pengertian yang kompleks yang melibatkan berbagai aspek kegiatan. Menurut Nurhadi (2004:14), tujuan membaca ada lima yaitu membaca untuk tujuan studi (telaah ilmiah), membaca untuk tujuan menangkap garis besar bacaan, membaca untuk menikmati karya sastra, membaca untuk mengisi waktu luang dan membaca untuk mencari keterangan tentang suatu istilah. Keterampilan membaca kelas VI SD Muhammadiyah Gantiwarno masih tergolong rendah sehingga guru sebagai fasilitator harus bisa menyajikan sebuah pembelajaran yang inovatif sehingga hasil belajara keterampilan membaca peserta didik dapat meningkat. Penggunaan media pembelajaran yang menarik akan membuat peserta didik lebih antusias dan pembelajaran lebih menyenangkan sehingga materi pembelajaran pun akan diterima baik oleh peserta didik. Kriteria Ketuntasan Minimal (KKM) untuk mata pelajaran Bahasa Indonesia dalam keterampilan membaca di SD Muhammadiyah Gantiwarno adalah 70 , sedangkan prosentase kelas VIB dalam materi mencari informasi penting bacaan berdasarkan analisis daya serap hasil belajar sebelumnya baru mencapai $66.48 \%$.

Dari hasil identifikasi masalah yang diuraikan di atas, maka dapat diketahui bahwa hasil belajara peserta didik kelas VI SD Muhammadiyah Gantiwarno dalam keterampilan membaca relatif rendah dikarenakan penggunaan media pembelajaran yang mash sederhana sehingga diperlukan sebuah media pembelajaran yang inovatif, efisien, dan menarik untuk menunjang pembelajaran keterampilan membaca. Menurut Sudjana (2009: 129) Media audio visual adalah media yang mempunyai unsur suara dan unsur gambar. Jenis media ini mempunyai kemampuan yang lebh baik. Media audio visual berasal dari penggabungan antara audio dan visual. Pengertian media audio dimaksud sebagai bahan yang mengandung pesan dalam bentuk auditif (pita suara atau piringan suara) yang dapat merangsang pikiran, perasaan, perhatian dan kemauan siswa.

Menurut Sutirman (2013: 15) media merupakan komponen sumber belajar atau wahana fisik yang mengandung materi instruksional di lingkungan siswa yang dapat merangsang siswa untuk belajar. Video pembelajaran dalam penelitian ini termasuk ke dalam media audio visual, di mana video pembelajaran tersebut dibuat menarik dengan animasi bergerak yang nantinya membuat peserta didik lebih antusias dan interaktif selama pembelajaran berlangsung sehingga mengubah tingkah laku peserta didik dalam hal hasil belajar yang lebih optimal. Penggunaan media audio visual untuk video pembelajaran merupakan salah satu perencaaan yang disiapkan guru dalam proses pembelajaranagar lebih menarik dan dapat memotivasi peserta didik dalam belajar. Video pembelajaran ini mengandalkan dua indera manusia sekaligus yaitu penndengaran (Audio) dan penglihatan (Visual), sehingga merupakan alat 
pembelajaran yang dapat dipergunakan dalam situasi belajar untuk membantu kata serta tulisan dalam menularkan pengetahuan, ide serta sikap peserta didik. Kedudukan media sangat membantu penyampaian materi yang melibatkan guru dan peserta didik secara langsung dalam mendukung proses belajar mengajar. Guru harus terampil dalam memanfaatkan media sebagai alat bantu mengajar dan harus disesuaikan dengan tujuan pembelajarannya.

Berdasarkan permasalahan yang terjadi di lapangan, maka perlu dicari solusi untuk permasalahan tersebut. Solusi tersebut diharapkan mampu meningkatkan keterampilan membaca pemahaman peserta didik. Salah satu solusi dari masalah tersebut adalah menggunakan media pembelajaran yang tepat. Oleh karena itu, peneliti mengambil PenelitianTindakn Kelas (PTK) yang berjudul "Peningkatan Keterampilan Membaca SD Muhammadiyah Gantiwarno melalui Media Video Pembelajaran"

\section{METODE}

Jenis penelitian ini adalah penelitian tindakan kelas (classroom action researh). Suharsimi (2010:17) mengemukakan model penelitian tindakan kelas secara garis besar terdapat empat tahapan yang lazim dilalui, yaitu (1) perencanaan, (2) pelaksanaan, (3) pengamatan, dan (4) refleksi. Penelitian tindakan kelas adalah proses investigasi terkendali untuk menemukan dan memecahkan masalah pembelajaran di kelas, proses pemecahan masalah tersebut dilakukan secara bersiklus, dengan tujuan untuk meningkatkan kualitas pembelajaran dan hasil pembelajaran di kelas tertentu. Subjek dalam penelitian ini adalah peserta didik kelas VIB SD Muhammadiyah Gantiwarno tahun pembelajaran 2020/2021. Penelitian dilaksanakan pada semester ganjil yaitu tanggal 27 Oktober 2020 sampai 23 November 2020 yang terdiri atas tiga siklus yaitu siklus I, siklus II, dan siklus III. Penelitian ini menggunakan beberapa teknik dalam mengumpulkan data selama proses penelitian. Teknik pengumpulan data yang digunakan berupa observasi, angket, dan dokumentasi. Peneliti dalam menerapkan media video pembelajaran pada penelitian ini menggunakan instrumen atau alat agar data yang diperoleh lebih lengkap dan detail. Instrumen penelitian yang digunakan dalam penelitian ini berupa lembar pengamatan guru dan peserta didik serta alat yang digunakan untuk merekam proses pembelajaran berupa handphone. Teknik analisis data yang digunakan dalam penelitian ini adalah analisis deskriptif kualitatif, yaitu teknik analisis data yang digambarkan dengan kata-kata atau kalimat.

\section{HASIL DAN PEMBAHASAN}

Pembelajaran mengenai keterampilan membaca dalam mencari informasi penting pada peserta didik kelas VIB SD Muhammadiyah Gantiwarno masih menggunakan media berupa buku atau teks bacaan, sehingga hasil belajar peserta diidk masih rendah. Tindakan pada siklus I ini dilakukan untuk mengatasi permasalahan tersebut. Peserta didik sebelumnya hanya menggunakan media buku pelajaran, namun ada siklus I ini peserta didik meningkatkan keterampilan membaca melalui sebuah video pembelajaran yang berupa slide materi dan gambar, sedangkan pada siklus II dan III menggunakan video pembelajaran animasi (gambar bergerak). Pada video tersebut dijelaskan tentang materi cara membaca yang baik dan cara mencari informasi penting dalam sebuah bacaan.

Perbaikan setiap siklusnya sudah terlihat baik dari hasil belajar maupun ketika proses pembelajaran. Guru sudah mampu menumbuhkan keaktifan pada peserta didik selama pembelajaran walaupun masih ada beberapa peserta didik yang belum aktif. Guru sudah melakukan perbaikan pada siklus II ini yaitu ketika pada siklus I guru belum melibatkan peerta didik dalam membuat kesimpulan materi opembelajaran, namun pada siklus II dan siklus III ini guru telah melibatkan peserta didik dalam membuat kesimpulan materi. Selain itu, guru juga telah melakukan perbaikan dengan 
melaksanakan refleksi di akhir pembelajaran bersama peserta didik. Penggunan video pembelajaran dengan animasi (gambar bergerak) dapat meningkatkan hasil belajar peserta didik kelas VIB SD Muhammdiyah Gantiwarno pada siklus II dan III. Selain itu, peserta didik yang di bawah Kriteria Ketuntasan Minimal (KKM) juga semakin berkurang. Berikut tabel hasil belajar peserta didik pada siklus I

Tabel 1. Hasil Belajar Peserta Didik Siklus I

\begin{tabular}{ccc}
\hline No & Range Nilai & $\begin{array}{c}\text { Jumlah Peserta didik } \\
\text { siklus I }\end{array}$ \\
\hline 1 & $90-100$ & 6 \\
\hline 2 & $80-89$ & 8 \\
\hline 3 & $70-79$ & 6 \\
\hline 4 & $60-69$ & 3 \\
\hline 5 & $50-59$ & \\
\hline 6 & $40-49$ & \\
\hline 7 & $30-39$ & \\
\hline 8 & $20-29$ & $\mathbf{6 0 . 8 7 \%}$ \\
\hline 10 & $10-19$ & $\mathbf{7 4 . 7 8}$ \\
\hline Ketuntasan Daya Serap
\end{tabular}

Berdasarkan tabel 1, tindakan yang dilakukan pada siklus I dikatakan berhasil mencapai indikator ketercapaian siklus I yaitu lebih dari $50 \%$ dari keseluruhan siswa kelas $\mathrm{VI}$ yang memperoleh $\mathrm{KKM}>70$ dari keterampilan membaca dalam mencari informasi penting bacaan. Namun, hasil yang diperoleh belum maksimal karena masih ada 9 peserta didik yang dibwah KKM. Perolehan rata-rata kelas siklus I mencapai 74.78 dengan ketuntasan daya serap mencapai $60.87 \%$. Langkah perbaikan dalam proses pembelajaran antara siklus I dan siklus II terdapat perbedaan pembelajaran antara siklus I dan siklus II. Perbedaan tersebut adalah apabila pada siklus I pembelajaran menggunakan media video pembelajaran slide materi, maka dalam siklus II pembelajaran menggunakan media video pembelajaran animasi (gambar bergerak).

Tabel 2. Hasil Belajar Peserta Didik Siklus II

\begin{tabular}{ccc}
\hline No & Range Nilai & $\begin{array}{c}\text { Jumlah Peserta didik } \\
\text { siklus II }\end{array}$ \\
\hline 1 & $90-100$ & 3 \\
\hline 2 & $80-89$ & 5 \\
\hline 3 & $70-79$ & 5 \\
\hline 4 & $60-69$ & 3 \\
\hline 5 & $50-59$ & 4 \\
\hline 6 & $40-49$ & 3 \\
\hline 7 & $30-39$ & \\
\hline 8 & $20-29$ & \\
\hline 9 & $10-19$ & \\
\hline Ketuntasan Daya Serap & $\mathbf{7 6 . 0 9}$ \\
\hline \multicolumn{3}{c}{ Rata-Rata Kelas } \\
\hline \multicolumn{3}{c}{} \\
\hline
\end{tabular}


Berdasarkan tabel 2, peneliti melaksanakan tindakan lebih lanjut dengan mangamati hasil belajar peserta didik melalui daya serap dan ketuntasan yang dicapai peserta didik dalam keterampilan membaca untuk mencari informasi penting bacaan. Hasil belajar peserta didik dalam pembelajaran keterampilan membaca untuk mencari informasi penting bacaan mengalami peningkatan. Hal tersebut dapat dilihat dari ratarata kelas yang meningkat menjadi 76.09 dan peserta didik yang di bawah Kriteria Ketuntasan Minimal (KKM) juga menurun menjadi 7 peserta didik dengan ketuntasan daya serap mencapai $69.56 \%$.

Tabel 3. Hasil Belajar Peserta Didik Siklus III

\begin{tabular}{ccc} 
No & Range Nilai & $\begin{array}{c}\text { Jumlah Peserta didik } \\
\text { siklus III }\end{array}$ \\
\hline 1 & $90-100$ & 7 \\
\hline 2 & $80-89$ & 4 \\
\hline 3 & $70-79$ & 5 \\
\hline 4 & $60-69$ & 3 \\
\hline 5 & $50-59$ & 5 \\
\hline 6 & $40-49$ & \\
\hline 7 & $30-39$ & \\
\hline 8 & $20-29$ & \\
\hline 9 & $10-19$ & $\mathbf{7 8 . 2 6 \%}$ \\
\hline 10 & $0-9$ & $\mathbf{8 2 . 1 7}$ \\
\hline \multicolumn{3}{c}{ Retuntasan Daya Serap } \\
\hline \multicolumn{3}{c}{ Rata-Rata Kelas } \\
\hline
\end{tabular}

Dalam tindak lanjut pada siklus III, pembelajaran meningkatkan keterampilan membaca peserta didik kelas VIB SD Muhammadiyah Gantiwarno menggunakan media video pembelajaran animasi (gambar bergerak), namun materi lebih detail daripada video pembelajaran siklus II. Hasil belajar peserta didik dalam pembelajaran keterampilan membaca untuk mencari informasi penting bacaan mengalami peningkatan. Hal tersebut dapat dilihat dari rata-rata kelas pada tabel 3 yang meningkat menjadi 82.17dan peserta didik yang di bawah Kriteria Ketuntasan Minimal (KKM) juga menurun menjadi 5 peserta didik dengan ketuntasan daya serap mencapai $78.26 \%$.

\section{SIMPULAN}

Berdasarkan pembahasan, Peneltian Tindakan Kelas dalam peningkatan keterampilan membaca mencari informasi penting bacaan pada peserta didik kelas VIB menggunakan media video pembelajaran ini dapat diambil kesimpulan bahwa penggunaan media berupa video pembelajaran dapat meningkatkan hasil belajar peserta didik pada setiap siklusnya, selain itu pembelajaran keterampilan membaca dalam mencari informasi penting juga terlihat aktif dan menyenangkan. Peserta didik yang dulu kurang aktif dan kurang berani bertanya menjadi aktif serta menunjukkan keberaniaanya untuk bertanya. Peningkatan proses pembelajaran yang baik berpengaruh terhadap hasil belajar siswa. Hasil nilai pembelajaran dalam keterampilan membaca untuk mencari informasi penting bacaan meningkat dari siklus 1 ke siklus II. Hasil Belajar pada siklus 1 menunjukkan masih ada sembilan peserta didik dari 23 peserta didik yang masih di bawah Kriteria Ketuntasan Minimal (KKM) dengan rata-rata kelas 74.78, sedangkan hasil belajar pada siklus II menunjukkan tujuh peserta didik masih di bawah Kriteria Ketuntasan Minimal (KKM) dengan rata-rata kelas 76.09. Hasil belajar pada siklus III menunjukkan lima peserta didik masih di bawah Kriteria Ketuntasan Minimal (KKM) dengan rata-rata kelas 82.17. 
Berdasarkan kesimpulan, saran yang dapat disampaikan dalam penelitian ini diantaranya, (1) media pembelajaran berupa video ini diharapkan dapat diterapkan dalam pembelajaran keterampilam membaca supaya tercipta pembelajaran aktif dan menyenangkan, (2) media pembelajaran yang digunakan guru sebaiknya inovatif, (3) bagi sekolah diharapkan penelitian ini dapat dijadikan bahan pertimbangan dalam rangka memajukan dan meingkatkan prestasi sekolah, khususnya dalam meningkatkan keterampilan membaca, dan (4) bagi peneliti lain diharapkan hasil penelitian ini dapat dijadikan sebagai acuan untuk melakukan penelitian dari sudut pandang yang berbeda.

\section{DAFTAR PUSTAKA}

Arikunto, Suharsimi. (2010). Penelitian Tindakan Kelas. Jakarta: PT Bumi Aksara.

Dimyati. (2006). Belajar dan Pembelajaran. Jakarta: Rineka Cipta

Nurhadi. (2004). Bagaimana Meningkatkan Kemampuan Membaca?. Bandung: Sinar Algensindo.

Sudjana, N. (2009). Penilaian Hasil Proses Belajar Mengajar. Bandung: PT Remaja Rosdakarya.

Sutirman. (2013). Media dan Model-Model Pembelajaran Inovatif. Yogyakarta: Graha IImu.

Tarigan, Henry Guntur. (2008). Membaca sebagai Suatu Keterampilan Berbahasa. Bandung: Angkasa. 